\title{
The Middle Dutch Reception of Geoffrey of Monmouth
}

\author{
David F. Johnson
}

Before discussing the traces of Geoffrey's works that have been identified in the vernacular literature of the medieval Low Countries, it may be useful to briefly review the highpoints of the Latin context for their reception in this region.

Pre-Galfridian References to King Arthur in the Medieval Low Countries

Anyone interested to learn whether Geoffrey of Monmouth's Latin writings were known in the medieval Low Countries ${ }^{1}$ may be surprised to discover that not only was this indeed the case, but that Arthur appears in Latin texts in the Low Countries even before Geoffrey published his famous De gestis Britonum $c .1138 .^{2}$ The two most notable such mentions of King Arthur in works penned in Latin by authors from the medieval Low Countries are found in Herman of Tournai's (also Herman of Laon, or in Dutch, Herman van Doornik) On the Miracles of St Mary of Laon (De miraculis S. Mariae Laudunensis), and in Lambert of St Omer's famous encyclopedia, the Liber Floridus. In the latter,

1 I use "Low Countries", "Netherlandic", and "The Netherlands" in their historical sense, to refer to what at the time was known as "Germania Inferior". As P.F.J. Obbema points out, this is the region comprising "what is now Belgium, the Netherlands, and the bordering Rhineland"; see "The Rooklooster Register Evaluated", Quaerendo 7 (1977), 326-53, at p. 33 o.

2 For information on the Latin Arthurian tradition in the medieval Low Countries, I have leaned heavily on two articles by G. Tournoy: "De Latijnse Artur in de Nederlanden", in W. Verbeke, J. Janssens, and M. Smeyers (eds.), Arturus Rex: Koning Artur en de Nederlanden: la matière de Bretagne et les anciens Pays-Bas (Mediaevalia Lovaniensia, Series 1, Studia 16), Leuven, 1987, pp. 147-88 and "A First Glance at the Latin Arthur in the Low Countries", in W. Van Hoecke, G. Tournoy, and W. Verbeke (eds.), Arturus Rex: Acta Conventus Lovaniensis 1987 (Mediaevalia Lovaniensia, Series 1, Studia 17), Leuven, 1991, pp. 215-21. For an exhaustive overview of the vernacular chronicle tradition in this region more broadly, see especially G.H.M. Claassens, "Niederländische Chronistik im Mittelalter", in G. Wolf and N.H. Ott (eds.), Handbuch Chroniken Des Mittelalters, Berlin, 2016, pp. 577-6o8. 
published in 1121, Lambert draws on the Historia Brittonum, among other sources, for material concerning Arthur that he includes in two chapters in this famous work (chapter 52, On the Marvels of Britain (De mirandis Britannie), and chapter 57, The History of the English (Historia Anglorum)). In chapter 52, Lambert recounts two legends concerning Arthur, the first of which tells of the stone in which is found the footprint of his dog, Cabal. Attempts to move the stone from atop its cairn are fruitless: no matter where one tries to hide it, by the third day one will find it back on top of the pile of stones Arthur himself had placed there. The second legend deals with the tomb erected by Arthur for his son Antyr, a tomb that yields different dimensions each time it is measured. Both of these were drawn from the Historia Brittonum, but Tournoy sees in Lambert's excision of the detail that it was Arthur himself who slew his son an intentional move to portray Arthur in a more positive light. ${ }^{3} \mathrm{~A}$ bit further on in this same chapter Lambert provides a description of Arthur's palace, which includes a sculptural depiction of his victories. According to Tournoy, this detail does not appear in any of the known redactions of the Historia Brittonum, nor may it be found in any of Lambert's other usual sources, which may or may not point in the direction of originality on the part of this author from the medieval Low Countries, though it does demonstrate a genuine pre-Galfridian interest in Arthur in the region. ${ }^{4}$ In chapter 57 , Lambert repeats the account of Arthur's twelve victories under the heading Historia Anglorum. ${ }^{5}$ The De miraculis $S$. Mariae Laudunensis is a saint's life written in 1142 by Herman van Doornik, abbot of St Martin's Abbey in Doornik/Tournai until 1136. Herman wrote it at the behest of the bishop of Laon, and it contains an account of the journeys of a number of canons of Laon through France and England to raise money to rebuild the cathedral of Laon, which was destroyed by fire in 1112. While traveling through Devonshire they are shown Arthur's chair and oven, and the travelers are told that they are in "Arthur's country". The relics the canons carry with them perform several miracles, but they fail to heal a local who argues with the French delegation, contending that Arthur still

3 See Tournoy, "De Latijnse Artur", pp. 149-50. For more on the autograph manuscript of Lambert's Liber Floridus, see especially A. Derolez, The Making and Meaning of the Liber Floridus: A Study of the Original Manuscript Ghent, University Library MS 92 (Studies in Medieval and Early Renaissance Art History, 76), London, 2015. The entire manuscript, Ghent, University Library, 92, is available in high resolution facsimile online at $<$ https://lib .ugent.be/catalog/rugo1:00o763774> (accessed 31 May 2018).

4 Tournoy, "De Latijnse Artur", p. 15 o.

5 Tournoy, "De Latijnse Artur", p. 150, and see Ghent, University Library, 92, fol. 72v for the passage in question. 
lives. ${ }^{6}$ If nothing else, these few references to King Arthur in the pre-Galfridian Latin writings of authors from the Low Countries demonstrate that the region would prove to be a fertile ground for the reception of Geoffrey's $D G B$ and $P M$. There is other evidence that speaks to the presence of a pre-Galfridian (oral) Arthurian tradition in this region as well, most notably a witness to a grant dating to 1118 by the name of "Walewein van Melle".

\section{The Reception of Geoffrey's Works in the Medieval Low Countries -} the Manuscripts

In his preliminary review of manuscripts with a Netherlandish provenance containing either the $D G B$ or the $P M$, Tournoy arrives at a total of some 20. He concludes that it is impossible to know how many there were in the region from the 12th century on, or how many have been lost. His review of published wills and testaments from the period turned up no references to copies of these works, and only one from a library catalogue from one of the seven collegiate churches of Liège, St Paul's. Records from the largest medieval libraries in the region - the monastic libraries - are more often than not very late and incomplete. The catalogues published by Antonius Sanderus in his Bibliotheca Belgica Manuscripta (Rijsel, 1641-44) list a number of tantalizing entries for manuscripts in some 11 Netherlandic monastic libraries, with titles that suggest copies, in whole or part, of Geoffrey's $D G B$ and $P M$. Unfortunately, in most cases we have no way of knowing when or where these manuscripts were written, or even which versions of the texts in question they contain. Equally tantalizing are references found in the monumental composite catalogue known as the Rooklooster Register, a manuscript that collects information from booklists compiled from 100 individual religious institutions in the medieval Low Countries. As Tournoy points out, the entry (under the sub-heading "Authors") on fol. 141v of this manuscript attributes texts that were most likely Geoffrey's $D G B$ and $P M$ to "Galfridus viterbiensis", which the compiler has corrected by consulting a manuscript in the Rooklooster itself: Nos habemus "Gaufridus

6 Tournoy, “De Latijnse Artur", pp. 147-48. See also A. Breeze, "Arthur in Early Saints' Lives", in S. Echard (ed.), The Arthur of Medieval Latin Literature: The Development and Dissemination of the Arthurian Legend in Medieval Latin (Arthurian Literature in the Middle Ages, 6), Cardiff, 2011, pp. 26-41, at p. 26, as well as J.S.P. Tatlock, "The English Journey of the Laon Canons", Speculum 8:4 (1933), 454-65.

7 For more on this Vualauuaynus, and further references, see G.H.M. Claassens and D.F. Johnson (eds.), King Arthur in the Medieval Low Countries (Mediaevalia Lovaniensia, Series 1, Studia 28), Leuven, 200o, pp. 4-5. 
monemutensis", "We have 'a Geoffrey of Monmouth". ${ }^{8}$ In the margin the scribe tells us that four other libraries owned exemplars of these texts, as well. Again, even if the information provided by these catalogues and booklists is sketchy and incomplete, it testifies to the presence and popularity of Geoffrey's Latin works. We are of course on much firmer ground when it comes to the manuscripts containing Geoffrey's works that are still preserved in archives and libraries in the Netherlands today, and Tournoy describes 11 of these that are known to have been compiled and to have resided in the medieval Low Countries. ${ }^{9}$ There is one further striking Latin text that deserves mention here, for it comprises an instance of an author from the Low Countries adapting Geoffrey's $D G B$ to his own ends, and in Tournoy's words, constitutes "the only attempt in the Latin literature of the Low Countries at a more personal reworking of Arthurian material". ${ }^{10}$ An otherwise unknown copyist by the name of Bernardus transcribed The Fall of Troy of Dares Phrygius and the $D G B$ at some point in the second half of the 12th century. He is thought to have been the one to insert a prologue and an epilogue, as well as a summary in leonine hexameters at the end of each one of the nine books of the $D G B$, after which he appends a summary of the legend of Brutus. In the prologue to this adaptation of the $D G B$, Bernardus tells his audience just how silly the idea is that Arthur will ever return.11

Geoffrey of Monmouth in Middle Dutch: Jacob van Maerlant and the Spiegel historiael

So far as we know, no integral translations of the $D G B$ or the $P M$ into Middle Dutch were ever produced. The reasons for this are unclear, though in the end

8 Tournoy, "De Latijnse Artur", p. 153. For more information on the Rooklooster Register and an ongoing project to publish this important manuscript online, see The Rooklooster Register Unveiled, Cartusiana and Österreichische Nationalbibliothek, 2009-13, <http:// rrkl.cartusiana.org/?q=node/7> (accessed 31 May 2018). The entry on fol. 141v may be consulted at $<\mathrm{http} / /$ rrkl.cartusiana.org/?q=image/view/354/_original $>$ (accessed 31 May 2018). For a good introduction to the manuscript in English, see Obbema, "The Rooklooster Register".

9 Tournoy, "De Latijnse Artur", pp. 153-55. All 11 of these manuscripts are more fully described in Crick, $S C$.

10 Tournoy, “A First Glance at the Latin Arthur", p. 216, and id., "De Latijnse Artur", pp. 155-56.

11 See J. Hammer, "Some Leonine Summaries of Geoffrey of Monmouth's Historia Regum Britanniae and Other Poems", Speculum 6:1 (1931), 114-23. The attribution of all of the leonine verses that appear in these two manuscripts (Douai, Bibliothèque municipale, 880 and 882) to Bernardus is called into question, however, by Crick, $D R$, p. 79 . 
it may simply be because Geoffrey's chronicle concerned mainly British history, and while it enjoyed a certain popularity in the medieval Low Countries in Latin, other chronicles and historiographical works, especially vernacular ones, took precedence over Geoffrey's work throughout the period. ${ }^{12}$ The road that leads to one of the most comprehensive incorporations of Geoffrey's $D G B$ in a Middle Dutch text actually begins with another Netherlandic chronicler, Sigebert of Gembloux, whose Latin Chronicle enjoyed wide circulation during the Middle Ages after his death in $1112 .{ }^{13}$ According to Geoffrey Ashe, Geoffrey of Monmouth may have borrowed the name of the Roman emperor Lucius from Sigebert's chronicle. ${ }^{14}$ Next we find that an anonymous monk from Ourscamp (near Beauvais) expanded Sigebert's Chronicle by adding material from the $D G B$ to produce the Auctarium Ursicampinum. ${ }^{15}$ Sometime after it was completed, this expanded version of Sigebert's Chronicle was then used by Vincent of Beauvais in composing his Speculum historiale, a text that brings us full circle back to the medieval Low Countries, for it was this work that the Flemish poet Jacob van Maerlant translated and reworked into his own vernacular Spiegel historiael ("Mirror of History"). When around 1283 Maerlant began work on an account of the history of the world in vernacular verse, which he dedicated to the man he hoped would become his patron, Floris v, count of Holland, he had already composed poems in Middle Dutch concerning that part of British history which involves the Arthurian legend, namely in his translations of the Old French Vulgate Cycle prose renderings of Robert de Boron's Estoire del Saint Graal and Estoire de Merlin. These works became known as the Merlijn, which consists of two parts, the first part as the Historie van den Grale, and the second under the title Boek van Merline. ${ }^{16}$ What concerns us here is that the version of history represented in the French works he adapted was something that Maerlant later came to distrust, and he includes many criticisms of his French sources in the text of his adaptive translation. By the time he began work on the Spiegel historiael, Maerlant had come to regard verse romances in French as lies and fables, and believed that if he could not find a source for something

12 See Claassens, "Niederländische Chronistik im Mittelalter", pp. 577-6o8.

13 See J. Deploige, "Sigebert of Gembloux", in R.G. Dunphy (ed.), Encyclopedia of the Medieval Chronicle, 2 vols., Leiden, 2010, vol. 2, pp. 1358-61, who notes that "in all, 65 manuscripts have been attested, of which more than 44 are preserved" (p. 1358).

14 Tournoy "A First Glance at the Latin Arthur", p. 218.

15 See Tournoy, "A First Glance at the Latin Arthur", pp. 218-19 for analysis of this monk's changes to the $D G B$ in his efforts to incorporate it into Sigebert's chronicle.

16 These texts have been most recently edited by T. Sodmann: Jacob van Maerlant, Historie van den Grale and Boek van Merline, ed. T. Sodmann, Jacob van Maerlant: Historie van den Grale und Boekvan Merline (Niederdeutsche Studien, 26), Cologne and Vienna, 1980. 
in Latin, it could not be true. ${ }^{17}$ Moreover, writing this history of the world for a secular court audience, he realized that he both had to trim his main source, Vincent of Beauvais' Speculum historiale, of much of its theological material, and look for a more expansive treatment of Arthurian history than was available in the Speculum historiale. ${ }^{18}$ Vincent of Beauvais seems not to have had a copy of the $D G B$ at his disposal, although his account of Arthurian history is ultimately based on it, being mediated through his main source, the expanded Chronicon of Sigebert of Gembloux, or Auctarium Ursicampinum. Maerlant, however, did have a copy of the $D G B$ to hand, and with the aid of this he expanded the brief Arthurian passage in Vincent of Beauvais' text - some 1500 words - to no fewer than 1500 lines of verse..$^{19}$ Most of the material Maerlant took from the $D G B$ to extend Vincent's terse treatment occurs in Books I, V, and VI of the Spiegel historiael. Of the seven chapters he devotes to Brutus in Book I, five contain material he drew from the $D G B$. In Chapter VII of Book V, Maerlant takes up the story of the Adventus saxonum, followed by other Arthurian highlights taken from Geoffrey such as Vortigern, the coming of Merlin, Aurelius Ambrosius, the death of Uther Pendragon, Arthur's accession to the throne, his subsequent conquests, his famous court, and his war with the Romans. Finally, it is in chapters 29 and 30 of Book vi that we find the account of the civil war between Arthur and Mordred, and the fateful battle on Salisbury Plain. ${ }^{20}$

\footnotetext{
17 For this aspect of his adaptation of these works, see especially W.P. Gerritsen, "Jacob van Maerlant and Geoffrey of Monmouth", in K. Varty (ed.), An Arthurian Tapestry: Essays in Memory of Lewis Thorpe, Glasgow, 1981, pp. 369-76. See also Claassens and Johnson (eds.), King Arthur, pp. 1-5.

18 Gerritsen, "Jacob van Maerlant", p. 377.

19 Gerritsen, "Jacob van Maerlant", pp. 378-79. In a note Gerritsen observes that he can find no material in the Speculum historiale that can be directly derived from the DGB. He notes Vincent's own admission that he lacked British sources to take his account of the English kings any further than 735 (p. 386, n. 39).

20 For an analysis of select passages influenced by the $D G B$ in Maerlant's Spiegel historiael, see Gerritsen, "Jacob van Maerlant", pp. 38o-83. The chapters containing the material from the $D G B$ are found in Jacob van Maerlant, Spiegel historiael [Mirror of history], ed. M. De Vries and E. Verwijs, Jacob van Maerlant, Philip van Utenbroeke, and Lodewijk van Velthem, Jacob van Maerlant's Spiegel historiael: met de fragmenten der later toegevoegde gedeelten [Jacob van Maerlant's Mirror of history: with the fragments of its later additions], 4 vols., Gravenhage, 1861-79 (repr. Utrecht, 1982), vol. 2, III Partie, I Boek, pp. 47-56; III Partie, v Boek, pp. 277-82, 333-43; and III Partie, vi Boek, pp. 386-88.
} 


\section{$4 \quad$ Geoffrey of Monmouth and the Lanceloet Compilation}

There is one further instance in Middle Dutch literature where Geoffrey's $D G B$ makes an appearance: the translation and adaptation of the Mort Artu in the final text in the so-called Lancelot Compilation: Arturs doet. The compiler of this manuscript took an existing translation into Middle Dutch of the Old French La Mort le Roi Artu and modified it to fit in his own Middle Dutch version, much expanded, of the Old French Vulgate Cycle. ${ }^{21}$ Here the compiler has removed the original passage concerning the battle between Arthur and the Romans he encountered in his exemplar, and replaced it, nearly verbatim, with its counterpart from Jacob van Maerlant's Spiegel historiael. ${ }^{22}$ Why he should have done so is a matter of debate. Gerritsen believes that it was out of deference for the more historically "accurate" version represented by Maerlant's translation of a Latin authority, whereas De Graaf maintains that its inclusion heightened the religious aspect of the text, a feature emphasized at the outset of this version of the story of Arthur's death with the addition of a prologue, unique to the Dutch text, redolent with religious meaning. ${ }^{23}$

21 For a convenient overview in English of this manuscript and the texts it contains, as well as its place in the landscape of Middle Dutch romance, see Claassens and Johnson (eds.), King Arthur, pp. 1-33.

22 Roman van Lancelot, ed. W.J.A. Jonckbloet, Roman van Lancelot (XIII e eeuw). Naar het (eenig-bekende) handschrift der Koninklijke Bibliotheek, op gezag van het Gouvernement uitgegeven door Dr. W.J.A. Janckbloet [The romance of Lancelot (13th century). Edited from the (only known) manuscript in the Royal Library, under the auspices of the government and edited by Dr. W.J.A. Janckbloet], 2 vols., Gravenhage, 1846-49, vol. 2, pp. 187-275, ll. 9683-10128. Compare Jacob van Maerlant, Spiegel historiael, ed. De Vries and Verwijs, vol. 2, pp. 335-43.

23 For the interpolation of this passage into Arturs doet, see especially K. de Graaf, "De episode van Arturs oorlog tegen de Romeinen", in Hoe Artur sinen inde nam: Studie over de Middelnederlandse ridderroman Arturs doet, Door een werkgroep van Groninger neerlandici ["The episode of Arthur's battle against the Romans" in How Arthur met his end: studies on the Middle Dutch romance Arturs doet, by a work group of medievalists at the University of Groningen], Groningen, 1983, pp. 207-14, and W.P. Gerritsen, "Lépisode de La Guerre Contre Les Romains Dans La Mort Artu Néerlandaise", in n.n. (ed.), Mélanges de Langue et de Littérature Du Moyen Age et de La Renaissance Offerts à Jean Frappier, 2 vols., Geneva, 1970, vol. 1, pp. 337-49. For more on the unique prologue at the outset of Arturs doet, see especially B. Besamusca and O.S.H. Lie, "The Prologue to Arturs doet, the Middle Dutch Translation of La Mort le Roi Artu in the Lancelot Compilation", in E. Kooper (ed.), Medieval Dutch Literature in its European Context (Cambridge Studies in Medieval Literature, 21), Cambridge, 1994, pp. 96-112. 